\title{
A Textual Interpretation of Mandailing Oral Tradition: A Cultural Maintenance Model
}

\author{
Mara Untung Ritonga \\ Universitas Negeri Medan \\ ritonga.unimed@gmail.com
}

\begin{abstract}
Language has the pivot on which the culture grow or turn to extinct. Language is as primary means of cultural events transmission. A digitalised adage as one of efforts to revitalise or maintain the culture will not be received without understanding the meanings of the oral tradition texts as their implicitness. This research tries to fill the space left by other researchers to make young generation of Mandailing understand the meanings of the oral tradition texts. The oral tradition tells a great deal of local genuine. By doing so, it is expected the young generation can pick out the beneficial messages from the oral tradition texts, then, to guide them in the action, behaviour, and thinking. Therefore, the oral traditonal needs to maintain or to reserve. With respect to the nature, the out put of this research is to design a maintenance model of Mandailing oral tradition. The subject of the research is the oral tradition of Mandailing analisyed through cognitive semantics, and CDA as theoretical tools for textual interpretation. The qualitative and quantitative data of the research show that the oral traditon of Mandailing; mangandung and marturi include in the category of extinct, while mangambat, mangalehenmangan, manjair, maralok-alok, mambue, marturas, maronangonang, marsilogo, marungut-ungut, and marpege-pege are in the category of endangered traditon. The cultural activities of the oral traditon do not transmit towards the young generation of Mandailing (age. 17- 40) taken from 100 respondent. Theydid not understand the meaning of the oral traditon texts (87\%). The other factor is very few young generation $(10 \%)$ involve in the cultural traditon of the oral tradition.
\end{abstract}

Keywords: oral tradition; maintenance model; textual interpretaion; local genuine

\section{Introduction}

Language maintenance programmed or done, particularlly ethnic language should maximally integrate ethnic literature (oral tradition) as a part of efforts to maintain or reserve language and culture.The oral traditon had long been known as cultural activities which transferred moral, values, and ideology of a cultural community when holding a weeding party, harvest time, proposing a girl to her parents, and the like. However, the cultural practices have rarely been found in the social community for many factors, such as, practical purpose, simple, cultural and language assimilation, rare cultural practitioners, mondernisation, and globalisation (Lubis, 2009, Nasution, 2015, Ritonga, 2016). Generally, the ethnic community of Mandailing in Tapanuli Selatan Sumatera Utara Indonesia uses their ethnic language as the first language (L1). However, the native of bahasa Mandailing decreases. They mostly use bahasa Indonesia instead of bahasa Mandailing. The table 1 below shows the position of bahasa Mandailing among other languages, that is, L1 (34.67\%), bahasa Indonesia (L2) is $57.45 \%$ and others are $7.88 \%$. The increase use of bahasa Indonesia is caused by bahasa Indonesia as bahasa nasional is used as means of transmission in education, government, and other formal situations. 


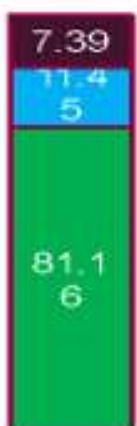

Angkola

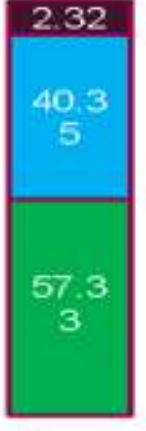

Karo
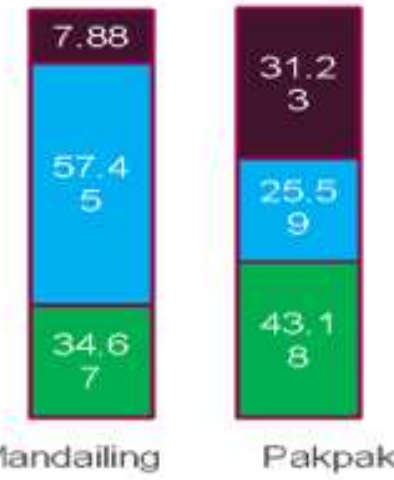

Pakpak

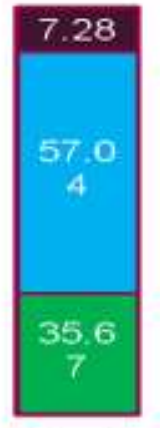

Simalungun
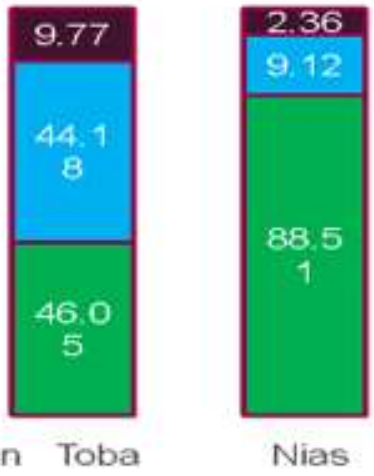

Nias

Figure 1. The Description of Ethnic Language Use in Sumatera Utara Indonesia Note: Ethnic language (B1), Bahasa Indonesia (B2), and other languages

The position of ethnic language as primary cultural activities transmission and interaction among speech community in the community (non-formal situation) is getting lower because the room to use it becomes less. This situation implies directly on the oral tradition or folklore in the wedding ceremonies and other cultural activities. In this respect, the government institution, language office and branch language offices, has maintained and revitalised many endangered ethnic languages and oral tradition as well as the publication of the works through digitised programmes in the internet and social media. Nevertheless, the efforts seem no effective without textual interpretation of the oral tradition as the young generation of Mandailing do not understand it. As a result, the cultural transmission process experience troubles and is cut -off. They just become audiences who enjoy the show of cultural events. If we do not do anything to change the condition, the culture of the oral tradition will be terminated by the time and digitalisation era.

\section{Review of Literature}

\subsection{Oral Tradition}

Oral tradition can be defined as social and cultural material transmitted orally as widespread mode of communication from generation to generation (see. Mournet, 2005, Suhartono, 2010). The oral tradition in the Mandailing culture contains local wisdom messages transmitted verbally in speeches in the form of songs or chants, poets, folktales, balads , sayings, and other cultural activities, like marpege-pege (fund collection from family, relatives and neighbours for holding a weeding party). Based on the observation, there are 14 kinds of Mandailing oral tradition; mangambat (welcoming a bride groom and his relative in a weeding ceremony), mangandung (a sadness feeling of parents and relative verbally transmitted in speech when a bridegroom takes a bride to his house), mangalehen mangan (serve food for a bridegroom and his close relatives), mangupa (to advice a bride and a bridegroom in the wedding party), manjeir, marolok-olok,(folktale), marpege-pege, mambue-bue ( giving a name to a baby), markobar (propose a girl to marry), marburas (work together to prepare a party) mronang-onang (traditonal song), marturi (folktale), marungut-ungut (traditional song)and marsilogo (traditonal song). This research takes one of the oral tradition 'marpege-pege' for a maintenance model. 


\subsection{Marepege-pege}

Marpege-pege is a cultural tradition in Mandailing community to help a member of the society to hold a wedding party in the term of material (finantial) and immaterial (participate in preparing the party). This has been a common pratice for Mandailing to make marpege-pege from generation to generation. Marpege-pege becomes a medium to establish a solid social relation in the cultural community of Mandailing. That is, to help each other when every member of community holds a wedding party from the begining (planning) until finishing. Every member of social community has the same chance to make marpege-pege when he plans to make a wedding party. Through this activity, a heavy work becomes light as it becomes together responsibility of its member community.However, this practice has been very rare lately.

A family who plans to make a wedding party should talk to a honorable man in the society or a cultural practitioner to invite the relatives and neighbours in the village. The host will serve food for all guests in the marpege-pege activity. The man and the woman who plans to marry also attend at the activity. After eating together, an honorable man or cultural practitioners pointed by the host to make a speech delivering the goal of the host. Then, the fund is collected from the guests (e.g. charity event, fund raising). Finally, the speaker announces the sum of fund collected, invitation to the guests at the day of the wedding party, and a plan to form a committee of wedding party. This committee member is young people, known as naposo bulung.Finally, the host and the brides shakehand all the guests as symbol of gratitude..

\subsection{Textual Interpretation}

The text of the oral tradition in the form of spoken or written is mostly implicit. Its implicitness that makes the oral tradition interesting, unique, and politness in ways of tranferring the messages through language (texts). Those are mostly orchestrated through figurative language; connotation, euphemisms, simile, and metaphors (see, Lakoff, 2003, Kövecses, 2006, 2010). The oral tradition which contains many local wisdom can not well be received without textual interpretation. Textual interpretation is aimed to make the meanings of the text easily grasped (explicit), for instance, language expression (1) below is taken from the honorable man speech in the 'marpege-pege' activity.

(1) Aek mangalir batu so (bahasa Mandailing /BM)

water flows stone stop

While the water flows, the stone remains remain unshaken.

The young generation of Mandailing will not understand the meaning of (1). To interprate the example (1), we should understand the language, context, culture, and ideology underlying the spoken text (1). This analysis or interpretation of the text (1) involves multidisciplinary approach; discourse, semanntics, pragmatics, cultural study, etc. Discourse varies depending on the field and goal, such cultural discourse, ideological discourse, political discourse, etc. Discourse is a kind of "social practice' (Weiss \& Wodak, 2003) which focuses on analytical research on the ways discourse structures enact, confirm, legitimate, reproduce, or challenge relations of power and dominance in society (Van Dijk, 1998: 353).

The text (1) also contains ideological aspect of being a good person in the society according to the culture of Mandailing. Van Dijk (2006) argues that Ideologies are sociocognitively defined as shared representations of social groups and more specifically as the 'axiomatic' principles of such representations. In this respect, we may understand the meaning of language in (1), if we have "linguistic knowledge and encycxlopedic knowledge' (Saeed, 
2010).Cognitive semantics assumes that language "reflects patterns of thought" (Evan \& Green, 2006: 5). Because language reflects patterns of thought, this means that to study language from this perspective is to study patterns of conceptualisation. To interprate the text (1), we should link to the concept of human in a social life in Mandailing culture sothat the conceptual sturcture hiding in (1) can be meaningful. In addition, People may not fully understand the meaning(1) without context knowledge. Context is very broad area, not just about the surrounding situation where the text taken or spoken. But everything from the external world, experiences or field following the linguistic units organising in the text or discourse (see. Wodak, 2003, Halliday, 2009, Martin, 2009, and Van Dijk, 2010).

The text (1) aboveis expressed in the 'marpege-pege' activity which refers to anyone attending at the meeting.It is a common cultural practicefor the honorable man (the oldest and respectful person in the community) give some advice. The advice is often expressed through metaphor as a way to be more polite and to show how to be an eloquent speaker. The text (1)is a piece ofadvice for the bride that she should be a person who likes to study during the life, listens to good pieces of advice and is not a talkative person. The word 'Aek' (water) symbolises a person (life), 'mangalir' (flow) symbolises the lesson or advice given. Then, 'batu' (stones) symbolises a person's brain, and 'so' (stop) means 'not working'. From (1) we can infer why this ethnic group compares or conceptualises the situation 'how water flows in the river with stones in it' to understand life. It is because they make use of their experience as farmers who are very familiar with the nature of the environment. They live in the countryside, in a mountainous area, they plant rice, breed fish, swim in the river, and so on. That is an example of how they make sense of their experience which Lakoff (2003) called "the experience of gestalt' (Gestalt psychology). The text (1) implicitly expresses a local wisdom, that is, being 'a low profile person' which means, although you have got married, have got children, and so on, you should get a long well with people, not to be a talkative person.

\section{Method and Data Collection}

Quallitative and quantitative method apply in the terms of questionnaires and semi structure interview. A questionnaire was distributed to 100 respondents age range from 17 to 40, consist of males (70), female (20), and 10 respondents aged 55 to 65 (males). The questionnaires are about their understanding about a piece of texts of oral tradition, their common knowledege about the Mandailing oral tradition, and their views about 'marpegepege. Whereas semi structure interviews were also about oral tradition issues conducted 5 times to 10 respndents from 5 villages.All respondents live in 5 villages: Batahan, Saba Dolok, Muara Siambak, Huta Baringin, and Huta Rimbaruof the district Kotanopan Tapanuli Selatan Sumatera Utara.Oral data are also taken from 'marpege-pege' activity through video-recording. Oral data are those data which are in the code of spoken language generated by people in the "natural context of verbal behaviour"'(Steen, 2007: 111).

\section{Discussion}

The data taken from questionnaire imply that mostly L1 respondents (87\%) do not understand the meanings of the piece of texts of the oral tradition. Other respondents (13\%) are pragmented into three categories; purely (6 respondents), good (4), and best (3). The respondents also wrote their comments about the oral tradition which mostly stated that the 
texts are not used a daily language of Mandailing, but, extraordinary language, full of wise words and proverb (umpasa). The purely understand respondent commented that they sometime watched and participated the cultural events of oral tradition, such as maronangonang and markobar eventhough they hardly understand the meanings but they enjoyed watching and hearing the tradition. The good respondents (40-45 age) stated that they often involved in the activity and studied from the elder people. Finally, the best one is because they are older (55-65) which often directly involved in the cultural events in their society or villages, and the cultural of oral tradition transmission at their era was well preserved and maintained.

The semi-structure interviews with 10 respondents are not much different from the questionnaire one. They commented that they like the oral tradition although the oral tradition have been very rare, particulary marturi-ture and mangandung. They also wanted to study and maintain the oral tradition. The respondents comments in line with the results of observation which describes that existing of Mandailing oral tradition as given below. The chart shows that 'the oral tradition of mangandung and marturi have been extinct. This is because there is no transmission from generation to generation, language and cultural contacts, cultural assimilation, etc. While other oral tradition posit on the endengared level. "Marpege-pege' for example, even thoguh it is very model of establishing harmony social relation in the community, it has become an uncommon practice for many reasons. Some of them are urbanisation factors, cultural assimilation, modernisation where people tend to be individualistic, globalisation and digitilisation. Those brings about impacts on the cut-off transmission from the old generation to the young one: (1) the persons who are expert in the Mandailing culture are very few, mostly the old one (60-70), (2) social and cultural structure of the community, such as hatobangon (respecful person, elderly), naposo bulung (young people), and paradaton (head of tradition), and dalihan natolu (brotherhood and brother in law concept) do not maintain well. The social and cultural structure have the main role in controlling cultural and social activities and problems in the community, such as marpegepege, wedding party, marburas, etc.

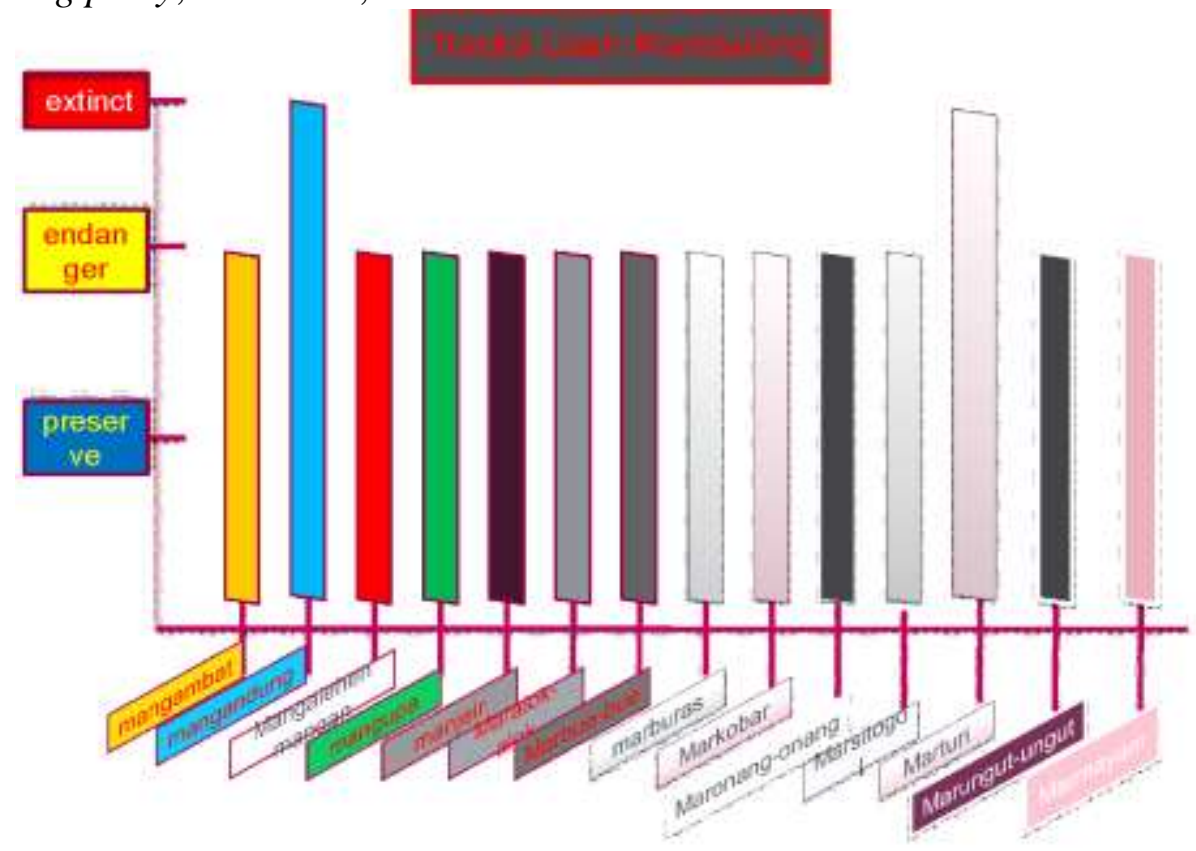

Chart 1. The Mandailing oral tradition description 
The population in the villages of Kotanopan had changed from homogeneous to be heterogeneous because of urbanisation, marriage, jobs, etc that influence the local wisdom effectivitiveness in ways of guiding the way of life in the social community. Prevously, the members of community used to actively take part in every social and cultural activity. They commonly obeyed the cultural and social norms which was effective in the society. As a result, the oral tradition transmission ran well from generation to generation. However, the condition changed from time to time, particularly,the effects of globalisation and digitalisation era. People, especially young generatioan seemed to be very busy with their gadgets. Social interaction moved from a real world to internet or social media. In the line with this situation, the language used also changed from L1 to L2, particularly for young generation. The ethnic pride and prestige changed as well where the young people tend to use bahasa Indonesia (12) instead of bahasa Mandailing (L2), not just in the formal places or situation, but also in the informal ones, such as interaction with friends, at markets, and houses.

The condition explained above causes the young generation did not understand the meanings of oral tradition texts. The culture can not live and grow without the presence of language. Therefore, some textual interpretations from the cultural activity of 'marpege-pege' (video recording data) are provided below as examplars.

(2) Opening speech from atobangon (old and honorable man)

Assalamu alaikum wr wb.

Parjolo do iba mandokon ata mauliatedi Tuhanta na gumorgalangit na tinompasitumandoktano sijongjongan, na dung mangalehen masorongkonatorkisan di ita rap marlagut di aratakni mora, di ari na saborngin on. Songon i musenganan solawat marsaretosalam di junjunganta Nabi Muhammad saw. Na dung patidaon dalan na tigor di ita sian narobi lopus tu ari na parpu.

(3) Politeness communication (speech act) to all guests in the house in the terms of apology.

Santabisapulu, sapulu noli marsantabi tu barisan ni mora marangka maranggi, songon i muse di anak boruna, boti ita sasudena naundulmarbanjar umaliangdi pantar ni mora di ari na saborngin on.

(4) Begining to say the goal of the host invitation

Di son sumurdudo napurannami na iring rongkon ata jamita, i ma martaringot di pomparan ni kahanggi niba na margorar Sinaloan. Ia tutu, sinuan tutas nami on madung godang boti ginjang pamatangna, na tumbursuang atutumbur ni robung, marunurandohot i,tarburtikma di sitamunangnanangkan manadingkonadat maposo mamolus adat matua bulung. (...) Baen i ma da gatal tangan nami tai inda binoto tu dia manggarukkon na.(..)

Three examplars of the texts in 'Marpege-pege' activity are translated respectively below.

Good night Gentlements,

Firstly, I would like to say thanks to the Almighty who has given us time and chance to gather in the house of 'Mora' (to be honoured man as the host whose daughter married to another tribe which will heritage his husband family name). And of course 
we say warmly greeting to our great prophet Muhammad Saw who has guided us to the right tracks from long ago until now.

I extremely would like to say my deep apology to 'mora and all his relative in this house and also to his brothers in law, and to all of us gathering here.

Here, we served 'sirih' (betel leaf) with words in it, that is about the son of our 'kahanggi' (a family name relation, example brother) named... where he has been adult and matured, there fore, he plans to get married, we gather in this house for this matter, that is to ask for help from relatives, friends, and neighbours (..)

Many language expressions of the exerpts (2-4) are implicit meaning in terms of metaphors and euphemisms, such as na gumorgalangit na tinompasitumandoktano sijongjongan,rongkon, marlagut di aratakni mora, parpu, undul, sumurdu, ata jamita (euphemism) andna tumbursuang atutumbur ni robung, marunuran, di sitamunangnanangkan manadingkonadat maposo mamolus adat matua bulungand gatal tangan nami tai inda binoto tu dia manggarukkon na. (metaphors). The ideology of 'marpege-pege' are expressed very subtle, polite, and indirectly, like gatal tangan nami tai inda binoto tu dia manggarukkon nataken from the text above.

(5) Gatal tangan nami, tai inda binoto tu dia manggarukkon na Itch hand our, but, do not know where to scratch it (We are low in money, and we want to ask for help)

The difficulties to understand the oral traditional texts make young generation absence in the cultural activities, and at last, the cultural transmission is cut off. There fore, it is necessarry to revitalise the function social and cultural structures and local wisdom of Mandaling through maintaining its oral tradition. The maintenance model of oral tradition is organised in the terms of social and cultural roles of the community members. The people should make a community meeting to elect; hatobongan, paradaton, parhata, naposo bulung, etc. The role of dalihan natolu also should be maintained in every social and cultural activity

\section{Conclusion}

With highly complex matters in ways of how to maintain the Mandailing oral tradition, it is necessary to make a maintenance model through empowering social and cultural roles of the people in the community according to the cultural concepts of the community. An academic approach has been made to transmit the oral tradition through textual interpretation. It is very important to do and to plan continuously as a language, literature, and cultural transmission from one generation to another. This textual interpretation is one of the ways to maintain and revitalise language and oral tradition to make the young generation understand the meanings of the texts and take the beneficial local wisdom messages to guide their action, behaviour, and thinking.

\section{References}

Bartlet, FC. (1965). Some Experiment on the Introduction of the Folk. in A. Dundes (ed) The Study of Folklore. Englewood. N.J: Prentice Hall.. 279298.

Evans, Vyvyan and Green, Melanie. (2006). Cognitive Linguistics: An Introduction, Edinburgh: Edinburgh University Press. 
Fairclough, Norman. (2003). Analyzing Discourse, London and New York: Routledge Taylor $\&$ Francis Group.

Lakoff, George and Johnson, Mark .(1980/2003). Metaphors We Live By, Chicago: The University of Chicago Press.

Kövesces, Zoltán. (2005). Metaphor in Culture: Universality and Variation, Cambridge: Cambridge University Press.

Kövesces, Zoltán. (2006). Language, Mind, and Culture, New York: Oxford University Press.

Martin. J.R. \& Rose. David. (2004). Working with Discourse: Meaning Beyond The Clause. London-New York: Continuum.

Mournet. C. Terence. (2005). Oral Tradition and Literary Dependency: Variability and Stability in the Synophic Tradition. Germany: Tubingen.

Ritonga, M.U. (2014). Exploration of Metaphor Use by Indonesial Legislators and Political Elites in the Indonesian Sociopolitical Domain. Birmingham UK. Aston University Press.

Saeed, I. John. (2003/2010). Cognitive Semantics, RRC: Blackwell Publisher Ltd.

Suhartono, at.al. (2010) Cerita Rakyat Pulau Mandangin. Kajian Struktural Antropologi Claude Levi Strauss 1 vol 23, nomor 4: 304. 311.

Van Dijk, Teun A. (2009). Society and Discourse: How Social Contexts Influence in Textand Talk, Cambridge: Cambridge University Press.

Wodak. R. \& Meyer. M. (2001) Method of Critical Discourse Analysis, London: Sage. 